Marquette University

e-Publications@Marquette

Chemistry Faculty Research and Publications

Chemistry, Department of

5-1-1991

Structure of 2,9-dimethyl-1,10-phenanthroline hemihydrate

Doyle Britton

University of Minnesota - Twin Cities

Larry C. Thompson

University of Minnesota - Duluth

Richard C. Holz

Marquette University, richard.holz@marquette.edu

Published version. Acta Crystallographica. Section C: Crystal Structure Communications, Vol. 47, No. 5 (May 1991): 1101-1103. DOI.C 1991 International Union of Crystallography. Used with permission.

Richard Holz was affiliated with the University of Minnesota - Duluth at the time of publication. 
Table 2. Molecular geometry

Bond distances $(\AA)$

$\begin{array}{llll}O(1)-N(1) & 1.396(2) & N(21)-C(9) & 1.462(3) \\ O(1)-C(6) & 1.395(3) & C(1)-C(2) & 1.356(3) \\ O(2)-N(21) & 1.227(3) & C(2)-C(3) & 1.421(3) \\ O(3)-N(21) & 1.221(3) & C(3)-C(4) & 1.417(3) \\ N(1)-C(1) & 1.354(3) & C(4)-C(5) & 1.355(3) \\ N(1)-C(5) & 1.346(3) & C(6)-C(7) & 1.397(3) \\ N(2)-C(6) & 1.307(3) & C(7)-C(8) & 1.370(4) \\ N(2)-C(10) & 1.343(3) & C(8)-C(9) & 1.393(3) \\ N(11)-C(3) & 1.324(3) & C(9)-C(10) & 1.375(3)\end{array}$

Bond angles $\left(^{\circ}\right)$

$\mathrm{N}(1)-\mathrm{O}(1)-\mathrm{C}(6)$

$\mathrm{O}(1)-\mathrm{N}(1)-\mathrm{C}(5)$

$\mathrm{O}(1)-\mathrm{N}(1)-\mathrm{C}(1)$

$113 \cdot 3(2)$

$118.4(2)$

$117 \cdot 7(2)$

$123 \cdot 8(2)$

$116 \cdot 6(2)$

C(6)-N(2)-C(10)

$\mathrm{O}(2)-\mathrm{N}(21)-\mathrm{O}(3)$

$123 \cdot 6(2)$

$118.9(2)$

$117 \cdot 6(2)$

$118.9(2)$

$120 \cdot 2(2)$

$\begin{array}{ll}\mathrm{N}(11)-\mathrm{C}(3)-\mathrm{C}(2) & 121 \cdot 3(2) \\ \mathrm{C}(2)-\mathrm{C}(3)-\mathrm{C}(4) & 117.6(2)\end{array}$

$\begin{array}{ll}\mathrm{N}(11)-\mathrm{C}(3)-\mathrm{C}(2) & 121 \cdot 3(2) \\ \mathrm{C}(2)-\mathrm{C}(3)-\mathrm{C}(4) & 117 \cdot 6(2)\end{array}$
$\mathrm{N}(11)-\mathrm{C}(3)-\mathrm{C}(4) \quad 121 \cdot 1(2)$

$\mathrm{C}(3)-\mathrm{C}(4)-\mathrm{C}(5) \quad 120 \cdot 2(2)$

$\mathrm{N}(1)-\mathrm{C}(5)-\mathrm{C}(4) \quad 119 \cdot 3(2)$

$\mathrm{O}(1)-\mathrm{C}(6)-\mathrm{N}(2) \quad 119 \cdot 4(2)$

$\mathrm{N}(2)-\mathrm{C}(6)-\mathrm{C}(7) \quad 126 \cdot 9(2)$

$\mathrm{O}(1)-\mathrm{C}(6)-\mathrm{C}(7) \quad 113 \cdot 7(2)$

$\mathrm{C}(6)-\mathrm{C}(7)-\mathrm{C}(8) \quad 116 \cdot 3(2)$

$\mathrm{C}(7)-\mathrm{C}(8)-\mathrm{C}(9) \quad 117.7(2)$

$\mathrm{N}(21)-\mathrm{C}(9)-\mathrm{C}(8) \quad 119 \cdot 5(2)$

$\mathrm{C}(8)-\mathrm{C}(9)-\mathrm{C}(10) \quad 121 \cdot 4(2)$

$\mathrm{N}(21)-\mathrm{C}(9)-\mathrm{C}(10) \quad 119 \cdot 1(2)$

Hydrogen-bond parameters $\left(\AA,{ }^{\circ}\right)$

$\begin{array}{lcccc}A-\mathrm{H} \cdots B & A-\mathrm{H} & \mathrm{H} \cdots B & A \cdots B & A-\mathrm{H} \cdots B \\ \mathrm{C}(5)-\mathrm{H} \cdots \mathrm{Cl}^{\mathrm{i}} & 0 \cdot 94(4) & 2 \cdot 48(3) & 3 \cdot 380(3) & 159(4) \\ \mathrm{C}(4)-\mathrm{H} \cdots \mathrm{Cl} & 0.88(5) & 2 \cdot 73(4) & 3.494(3) & 146(4) \\ \mathrm{N}(11)-\mathrm{H}(11) \cdots \mathrm{Cl} & 0.85(4) & 2 \cdot 41(4) & 3.251(3) & 169(4) \\ \mathrm{N}(11)-\mathrm{H}(12) \cdots \mathrm{Cl}^{\mathrm{ii}} & 1 \cdot 04(3) & 2 \cdot 23(3) & 3.260(3) & 172(3)\end{array}$

Symmetry code: (i) $x, y, z$; (ii) $x+\frac{1}{2},-y-\frac{1}{2}, z$; (iii) $-x+\frac{1}{2}, y+\frac{1}{2}$, $z-\frac{1}{2}$.

CRYSRULER programs (Rizzoli, Sangermano, Calestani, Andreetti, 1986). The final atomic parameters are listed in Table $1,{ }^{*}$ bond distances, angles

* Lists of structure factors, anisotropic thermal parameters and $\mathrm{H}$-atom parameters have been deposited with the British Library Document Supply Centre as Supplementary Publication No. SUP 53490 (11 pp.). Copies may be obtained through The Technical Editor, International Union of Crystallography, 5 Abbey Square, Chester $\mathrm{CH} 12 \mathrm{HU}$, England.

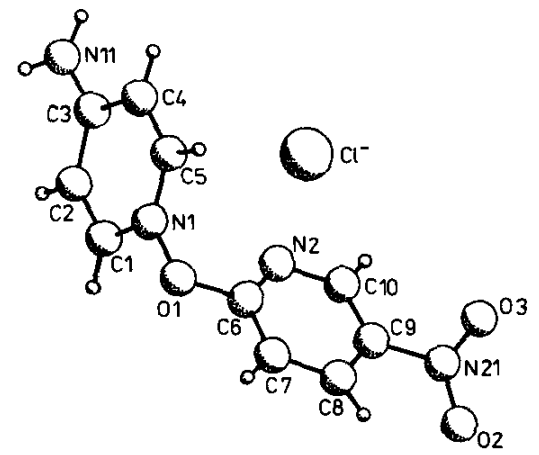

Fig. 1. A view of the molecule with the numbering of the atoms.

and hydrogen bonds in Table 2. Fig. 1 shows a view of the molecule with the numbering of the atoms.

Related literature. Preparation of similar compounds is given in Kalinowski, Rykowski \& NantkaNamirski (1984).

Intensities were measured at the Institute of Technical Biochemistry, Technical University of Łódź. This work was supported by project R.P.II.10 from MEN.

\section{References}

Kalinowski, J., Rykowski, A. \& NantKa-Namirski, P. (1984). Pol. J. Chem. 58, 125-134.

Main, P., Fiske, S. J., Hull, S. E., Lessinger, L., Germain, G., DEClerCQ, J.-P. \& WoOLFSON, M. M. (1980). MULTAN80. A System of Computer Programs for the Automatic Solution of Crystal Structures from $X$-ray Diffraction Data. Univs. of York, England, and Louvain, Belgium.

Rizzoli, C., Sangermano, V., Calestani, G. \& Andreetti, G. D. (1986). CRYSRULER. Version 1.1, Polish version. Univ. degli Studi di Parma, Italy.

SHELDRICK, G. M. (1976). SHELX76. Program for crystal structure determination. Univ. of Cambridge, England.

Acta Cryst. (1991). C47, 1101-1103

\title{
Structure of 2,9-Dimethyl-1,10-phenanthroline Hemihydrate
}

\author{
By DOYle BritTon \\ Department of Chemistry, University of Minnesota, Minneapolis, MN 55455, USA \\ AND LARRy C. Thompson and RichaRd C. Holz \\ Department of Chemistry, University of Minnesota, Duluth, MN 55812, USA
}

(Received 20 June 1990; accepted 9 October 1990)

Abstract. $\mathrm{C}_{14} \mathrm{H}_{12} \mathrm{~N}_{2} \cdot \frac{1}{2} \mathrm{H}_{2} \mathrm{O}, \quad M_{r}=217 \cdot 27$, tetragonal,
$I 4{ }_{1} / a, \quad a=14 \cdot 258(3), \quad c=22 \cdot 286(4) \AA, \quad V=$
$\begin{aligned} & 4531(3) \AA^{3}, Z=16, D_{x}=1 \cdot 274(1) \mathrm{g} \mathrm{cm}^{-3}, \mathrm{Mo} K \alpha \\ & \text { radiation, } \lambda=0 \cdot 71073 \AA, \mu=0.74 \mathrm{~cm}^{-1}, F(000)= \\ & 0108-2701 / 91 / 051101-03 \$ 03.00\end{aligned}$

1840, $T=297 \mathrm{~K}, \quad R=0.041$ for 1196 unique observed reflections with $I>2 \sigma(I)$. Pairs of dimethylphenanthroline molecules related by a twofold axis are bridged by water molecules lying on the (C) 1991 International Union of Crystallography 
Table 1. Fractional atomic coordinates and equivalent isotropic temperature factors

\begin{tabular}{lcccc}
\multicolumn{5}{c}{$B_{\mathrm{eq}}=\left(8 \pi^{2} / 3\right) \sum \sum_{j} U_{i j} a_{i}^{*} a_{j}^{*} \mathbf{a}_{i} \cdot \mathbf{a}_{j} \cdot$} \\
N1 & $x$ & $y$ & $z$ & $B_{\mathrm{eq}}\left(\AA^{2}\right)$ \\
N2 & $0.1364(1)$ & $0.2438(1)$ & $0.84922(7)$ & $4 \cdot 3(1)$ \\
C1 & $0.1042(1)$ & $0.4310(1)$ & $0.86844(8)$ & $4.5(1)$ \\
C2 & $0.1511(2)$ & $0.1535(2)$ & $0.8399(1)$ & $4 \cdot 8(1)$ \\
C3 & $0.1528(2)$ & $0.1141(2)$ & $0.7822(1)$ & $5.6(1)$ \\
C4 & $0.1398(2)$ & $0.1700(2)$ & $0.7338(1)$ & $5.7(1)$ \\
C5 & $0.1242(2)$ & $0.2658(2)$ & $0.7416(1)$ & $4.6(1)$ \\
C6 & $0.1110(2)$ & $0.3287(2)$ & $0.6925(1)$ & $5.9(1)$ \\
C7 & $0.0961(2)$ & $0.4204(2)$ & $0.7017(1)$ & $6 \cdot 0(1)$ \\
C8 & $0.0928(2)$ & $0.4578(2)$ & $0.7611(1)$ & $5.0(1)$ \\
C9 & $0.0763(2)$ & $0.5528(2)$ & $0.7726(1)$ & $6.2(2)$ \\
C10 & $0.0734(2)$ & $0.5842(2)$ & $0.8298(1)$ & $6.1(1)$ \\
C11 & $0.0878(2)$ & $0.5213(2)$ & $0.8775(1)$ & $5.2(1)$ \\
C12 & $0.1060(1)$ & $0.3989(2)$ & $0.8109(1)$ & $4.1(1)$ \\
C13 & $0.1223(1)$ & $0.2999(2)$ & $0.80104(9)$ & $4.0(1)$ \\
C14 & $0.1655(2)$ & $0.0933(2)$ & $0.8946(1)$ & $6.7(2)$ \\
O11 & $0.0853(2)$ & $0.5531(2)$ & $0.9417(1)$ & $7.1(2)$ \\
H1 & 0 & 0.25 & $0.9528(1)$ & $8.7(2)$ \\
& $0.051(3)$ & $0.269(4)$ & $0.921(2)$ & $19(2)$
\end{tabular}

Table 2. Bond lengths $(\AA)$ and angles $\left(^{\circ}\right)$

\begin{tabular}{|c|c|c|c|}
\hline $\mathrm{N} 1-\mathrm{Cl}$ & $1 \cdot 322(3)$ & $\mathrm{C} 6-\mathrm{C} 7$ & $1.427(4)$ \\
\hline $\mathrm{N} 1-\mathrm{C} 12$ & $1.353(3)$ & $\mathrm{C} 7-\mathrm{C} 8$ & $1.399(4)$ \\
\hline $\mathrm{N} 2-\mathrm{C} 10$ & $1.325(3)$ & C7-CII & $1.404(3)$ \\
\hline $\mathrm{N} 2-\mathrm{C} 11$ & $1.362(3)$ & $\mathrm{C} 8-\mathrm{C} 9$ & $1 \cdot 352(4)$ \\
\hline $\mathrm{C} 1-\mathrm{C} 2$ & $1.405(4)$ & $\mathrm{C} 9-\mathrm{C} 10$ & 1.406 (4) \\
\hline $\mathrm{Cl}-\mathrm{Cl} 3$ & $1 \cdot 504(4)$ & $\mathrm{Cl} 0-\mathrm{Cl} 4$ & $1.501(4)$ \\
\hline $\mathrm{C} 2-\mathrm{C} 3$ & 1.355 (4) & $\mathrm{Cl1}-\mathrm{C} 12$ & $1.448(3)$ \\
\hline $\mathrm{C} 3-\mathrm{C} 4$ & $1.394(4)$ & $\mathrm{O} 11-\mathrm{H} 1$ & $1.06(4)$ \\
\hline $\mathrm{C} 4-\mathrm{C} 12$ & $1.411(3)$ & $\mathrm{N} 1-\mathrm{HI}$ & $2.03(4)$ \\
\hline $\mathrm{C} 4-\mathrm{C} 5$ & $1.427(4)$ & $\mathrm{N} 1-\mathrm{O} 11$ & $3.020(3)$ \\
\hline $\mathrm{C} 5-\mathrm{C} 6$ & $1 \cdot 341$ (5) & & \\
\hline $\mathrm{Cl}-\mathrm{N} 1-\mathrm{Cl} 2$ & $118 \cdot 3(2)$ & $\mathrm{C} 9-\mathrm{C} 8-\mathrm{C} 7$ & 119.9 (3) \\
\hline $\mathrm{C} 10-\mathrm{N} 2-\mathrm{Cll}$ & $118.3(2)$ & $\mathrm{C} 8-\mathrm{C} 9-\mathrm{C} 10$ & $119.8(2)$ \\
\hline $\mathrm{N} 1-\mathrm{Cl}-\mathrm{C} 2$ & $122.4(2)$ & $\mathrm{N} 2-\mathrm{Cl} 1-\mathrm{C} 9$ & $122.1(2)$ \\
\hline $\mathrm{N} 1-\mathrm{Cl}-\mathrm{C} 13$ & $116.8(2)$ & $\mathrm{N} 2-\mathrm{Cl}-\mathrm{Cl} 4$ & $116 \cdot 3(2)$ \\
\hline $\mathrm{C} 2-\mathrm{Cl}-\mathrm{C} 13$ & $120.8(2)$ & $\mathrm{C} 9-\mathrm{C} 10-\mathrm{Cl} 4$ & $121 \cdot 6(2)$ \\
\hline $\mathrm{C} 3-\mathrm{C} 2-\mathrm{Cl}$ & $119 \cdot 4(2)$ & $\mathrm{N} 2-\mathrm{C} 11-\mathrm{C} 7$ & $122.7(2)$ \\
\hline $\mathrm{C} 2-\mathrm{C} 3-\mathrm{C} 4$ & $120.0(2)$ & $\mathrm{N} 2-\mathrm{C} 11-\mathrm{C} 12$ & $118.3(2)$ \\
\hline $\mathrm{C} 3-\mathrm{C} 4-\mathrm{C} 12$ & $117.2(2)$ & $\mathrm{C} 7-\mathrm{C} 11-\mathrm{C} 12$ & $119.0(2)$ \\
\hline $\mathrm{C} 3-\mathrm{C} 4-\mathrm{C} 5$ & $122.7(2)$ & $\mathrm{N} 1-\mathrm{C} 12-\mathrm{C} 4$ & $122.6(2)$ \\
\hline $\mathrm{C} 12-\mathrm{C} 4-\mathrm{C} 5$ & $120 \cdot 1(2)$ & $\mathrm{N} 1-\mathrm{C} 12-\mathrm{C} 11$ & $118 \cdot 6(2)$ \\
\hline $\mathrm{C} 6-\mathrm{C} 5-\mathrm{C} 4$ & $121 \cdot 0(2)$ & $\mathrm{C} 4-\mathrm{Cl}-\mathrm{Cl1}$ & $118.7(2)$ \\
\hline $\mathrm{C} 5-\mathrm{C} 6-\mathrm{C} 7$ & $120.8(2)$ & $\mathrm{H} 1-\mathrm{O} 11-\mathrm{H} 1^{\prime}$ & $95(3)$ \\
\hline $\mathrm{C} 8-\mathrm{C} 7-\mathrm{C} 11$ & $117.2(2)$ & $\mathrm{O} 11-\mathrm{H} 1-\mathrm{N} 1$ & $154(3)$ \\
\hline $\mathrm{C} 8-\mathrm{C} 7-\mathrm{C} 6$ & $122.5(2)$ & $\mathrm{N} 1-\mathrm{O} 11-\mathrm{N} 1$ & $80.3(2)$ \\
\hline $\mathrm{C} 11-\mathrm{C} 7-\mathrm{C} 6$ & $120 \cdot 3(2)$ & & \\
\hline
\end{tabular}

twofold axis and $\mathrm{H}$ bonded to one of the $\mathrm{N}$ atoms in each molecule. The $\mathrm{H}$ bonds are long and far from linear: $\mathrm{O}-\mathrm{H} \quad 1.06(4), \quad \mathrm{H} \cdots \mathrm{N} \quad 2.03(4), \quad \mathrm{O} \cdots \mathrm{N}$ 3.020 (3) $\AA ; \mathrm{O}-\mathrm{H} \cdots \mathrm{N} 154(3)^{\circ}$. This is presumably a consequence of the approximately parallel arrangement of the two phenanthroline molecules in the (phen) $)_{2} \cdot \mathrm{H}_{2} \mathrm{O}$ complex, which are tilted $4.7(1)^{\circ}$ with respect to each other; the atoms in one molecule are 3.50 to $3.81 \AA$ from the plane of the other molecule. On the other side of the phenanthroline is another phenanthroline related by a center of symmetry with the atoms of one molecule 3.41 to $3.45 \AA$ from the plane of the other molecule. The phenanthroline molecule has close to $2 \mathrm{~mm}$ symmetry, but the indivi- dual $\mathrm{C}_{6}$ rings are tilted about $1^{\circ}$ with respect to each other.

Experimental. High-quality crystals of the title compound were obtained as a by-product in the synthesis of metal complexes with the compound as a ligand. A regular octahedron, $0.50 \times 0.50 \times 0.50 \mathrm{~mm}$, was used for the data collection. Data were collected on an Enraf-Nonius CAD-4 diffratometer equipped with a graphite monochromator. 25 reflections with $11<\theta<19^{\circ}$ were used to determine the cell parameters. Systematic extinctions $(h k l, h+k+l$ odd; $h k 0$, $h$ odd; $00 l, l \neq 4 n)$ uniquely determined the space group. Data were collected, using $\omega$ scans, in the range $0<\theta<25^{\circ}$ for one quadrant (ranges: $h-16$ to $16, k 0$ to $16, l 0$ to 26 ). No absorption corrections were made. 4255 reflections were measured and averaged to give 2048 independent reflections $\left(R_{\text {int }}=\right.$ $0.041)$ of which the 1196 with $I>2 \sigma(I)$ were used in the calculations. Three check reflections measured every $6000 \mathrm{~s}$ of exposure time showed no systematic change with time. A trial structure was found using the direct-methods program MITHRIL (Gilmore, 1984). All atoms except $H$ were given anisotropic thermal parameters. The aromatic $\mathrm{H}$ atoms were included at idealized positions with isotropic thermal parameters $20 \%$ larger than the isotropic equivalent of the attached atoms. Since idealized positions could not be predicted for the $\mathrm{H}_{2} \mathrm{O}$ and $\mathrm{CH}_{3} \mathrm{H}$ atoms; they were located from difference Fourier maps. The $\mathrm{H}_{2} \mathrm{O} \mathrm{H}$ atoms were refined as independent atoms with an isotropic thermal parameter. The $\mathrm{CH}_{3}$ $\mathrm{H}$ atoms were refined as $\mathrm{H}_{3}$ groups with idealized distances but with variable orientations and group isotropic thermal parameters. All parameters were refined by full-matrix least-squares techniques on $F$ 's. Refinement converged with $R=0.041, w R=$

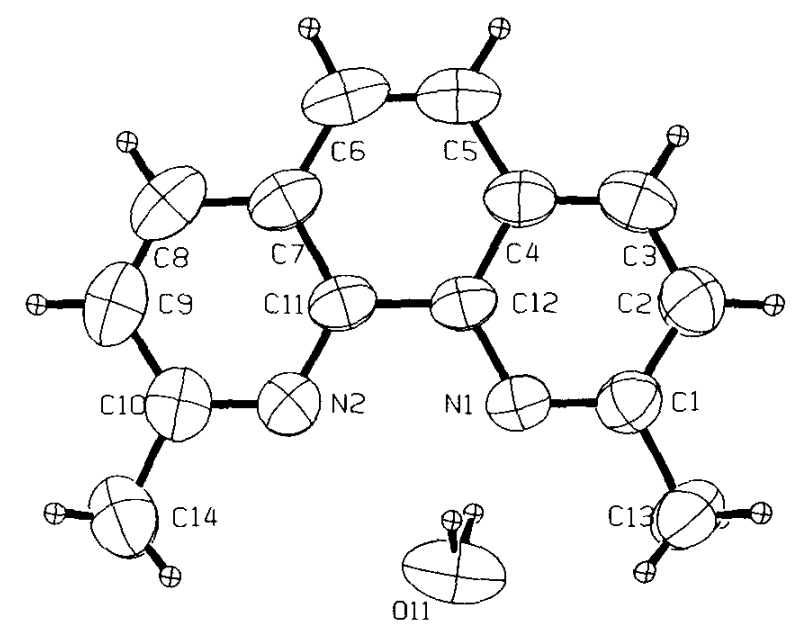

Fig. 1. $\left(\mathrm{CH}_{3}\right)_{2} \mathrm{C}_{12} \mathrm{H}_{6} \mathrm{~N}_{2} \cdot \frac{1}{2} \mathrm{H}_{2} \mathrm{O}$. Thermal ellipsoids are shown at the $50 \%$ probability level. The $\mathrm{O} 11$ atom lies on a twofold axis that in projection passes above the $\mathrm{C} 4$ atom. $\mathrm{H}$ atoms are shown with arbitrary size. 
$0.051, S=1.72 ; w=1 / \sigma^{2}(F)$ was calculated from $\sigma^{2}(I)=\sigma^{2}\left(I_{c}\right)+(0.04)^{2}$, where $\sigma\left(I_{c}\right)$ is the standard deviation in $I$ based on counting statistics alone. $(\Delta / \sigma)_{\max }$ in the final cycle was 0.06. $(\Delta \rho)_{\max }=0.17$, $(\Delta \rho)_{\min }=-0.13 \mathrm{e} \AA^{-3}$. The four highest peaks in the final difference Fourier map are near the $\mathrm{CH}_{3}$ groups suggesting that there is some disorder in their orientations. Atomic scattering factors and anomalous-dispersion corrections for all atoms were taken from International Tables for $X$-ray Crystallography (1974, Vol. IV). The computer programs used were from TEXSAN (Molecular Structure Corporation, 1985).

Atomic coordinates are given in Table 1 and interatomic distances and angles in Table 2.* The atomic labelling and thermal ellipsoids are shown in Fig. 1.

Related literature. Sen (1969) reported the same space group and unit cell for the title compound, dmp. $\frac{1}{2} \mathrm{H}_{2} \mathrm{O}$, although he did not recognize the presence of the water molecule. His experimental density, $1.27 \mathrm{~g} \mathrm{~cm}^{-3}$, is in excellent agreement with our calculated value. Watson, Galloy, Vögtle \& Müller (1984) have reported the structure of the $1 / 1$ complex of dmp with resorcinol. The only other

\footnotetext{
* Lists of anisotropic thermal parameters, H-atom parameters, intermolecular distances, least-squares planes, and observed and calculated structure factors have been deposited with the British Library Document Supply Centre as Supplementary Publication No. SUP 53642 (27 pp.). Copies may be obtained through The Technical Editor, International Union of Crystallography, 5 Abbey Square, Chester $\mathrm{CH} 1$ 2HU, England.
}

reported structure involving free $\mathrm{dmp}$ is that of $\mathrm{Zn}(\mathrm{dmp})(\mathrm{CN})_{2} \cdot \mathrm{dmp} \cdot 3 \mathrm{H}_{2} \mathrm{O}$ (Monge, Martínez-Ripoll \& García-Blanco, 1978). The structure of the $\mathrm{dmpH}{ }^{+}$ion has been reported in the $\mathrm{FeCl}_{4}^{-}$salt (Veidis, Witten, Reiff, Brennan \& Garafalo, 1981).

There are also about two dozen structures reported where dmp is a ligand in a metal complex. The most recent of these are $\mathrm{Cu}(\mathrm{dmp})\left(\mathrm{CH}_{3} \mathrm{CN}\right)^{+}$ (Munakata, Maekawa, Kitagama, Matsuyama \& Masuda, 1989), $\quad R u(d m p)(o-p h e n)_{2}^{2+} \quad$ (Ichida, Tachigashiki \& Sasaki, 1989) and $\mathrm{Cu}(\mathrm{dmp})(\mathrm{CN})_{2}^{-}$ (Ogura, Shemish, Scott, Pyrka \& Fernando, 1988).

LCT would like to thank the Research Corporation for their support of this work.

\section{References}

Gilmore, C. J. (1984). J. Appl. Cryst. 17, 42-46.

ICHIDA, H., TACHIGaShiki, S. \& SASAKI, Y. (1989). Chem. Lett. pp. $1579-1580$.

Molecular Structure Corporation (1985). TEXSAN. TEXRAY Structure Analysis Package. MSC, 3200A Research Forest Drive, The Woodlands, TX77381, USA.

Monge, A., Martínez-Ripoll, M. \& García-Blanco, S. (1978). Acta Cryst. B34, 2847-2850.

Munakata, M., Maekawa, M., Kitagama, S., Matsuyama, S. \& Masuda, H. (1989). Inorg. Chem. 289, 4300-4302.

Ogura, T., Shemish, E., Scott, N., Pyrka, G. J. \& Fernando, Q. (1988). Inorg. Chim. Acta, 149, 57-62.

SEN, D. K. (1969). Acta Cryst. B25, 988.

Veidis, M. V., Witten, E. H., Reiff, W. M. Brennan, J. F. \& Garafalo, A. R. (1981). Inorg. Chim. Acta, 54, L133-L135.

Watson, W. H., Galloy, J., Vögtle, F. \& Müller, W. M. (1984). Acta Cryst. C40, 200-202.

Acta Cryst. (1991). C47, 1103-1105

\title{
Structure of 7-Methoxy-2-(2-methoxyphenyl)-4H-1-benzopyran-4-one (2',7-Dimethoxyflavone)
}

\author{
By J. C. Wallet and E. M. Gaydou \\ Laboratoire de Phytochimie, ENSSPICAM, Faculté des Sciences et Techniques de Saint-Jerôme, \\ Avenue Escadrille Normandie-Niemen, 13397 Marseille CEDEX 13, France \\ J. Feneau-Dupont, B. Tinant and J.-P. DeClerce \\ Laboratoire de Chimie Physique et de Cristallographie, Université Catholique de Louvain, \\ 1 place Louis Pasteur, 1348 Louvain-la-Neuve, Belgium
}

AND A. BALDY

CNRS, UAR 1411, Faculté des Sciences et Techniques de Saint-Jerôme, 13397 Marseille CEDEX 13, France

(Received 23 May 1990; accepted 17 September 1990) Abstract. $\mathrm{C}_{17} \mathrm{H}_{14} \mathrm{O}_{4}, M_{r}=282 \cdot 30$, monoclinic, $P 2_{1} / c$,
$a=12 \cdot 498(4), b=9 \cdot 490(2), \quad c=12 \cdot 184(2) \AA, \quad \beta=$
$107.87(2)^{\circ}, \quad V=1375 \cdot 4(6) \AA^{3}, \quad Z=4, \quad D_{x}=$

0108-2701/91/051103-03\$03.00
$1.36 \mathrm{~g} \mathrm{~cm}^{-3}, \mathrm{Cu} K \alpha, \lambda=1.54178 \AA, \mu=7.98 \mathrm{~cm}^{-1}$, $F(000)=592, \quad T=291 \mathrm{~K}, \quad R=0.042$ for 1848 observed reflections. The benzopyran heterocycle is 